\title{
PENGARUH BERAT PATI DAN VOLUME PLASTICIZER GLISEROL TERHADAP KARAKTERISTIK FILM BIOPLASTIK PATI KENTANG
}

\author{
Afiifah Radhiyatullah*, Novita Indriani, M. Hendra S. Ginting \\ Departemen Teknik Kimia, FakultasTeknik,Universitas Sumatera Utara, \\ Jl. Almamater Kampus USU Medan 20155, Indonesia \\ *Email : afiifahrchan@gmail.com
}

\begin{abstract}
Abstrak
Bioplastik merupakan plastik yang dapat terdegradasi oleh mikroorganisme dan terbuat dari bahan yang dapat diperbaharui. Film plastik pati ini dibuat mengunakan pati kentang (kandungan pati yang terdapat pada kentang sebesar 22-28\%), gliserol sebagai plasticizer dan asam asetat sebagai katalis. Penelitian ini bertujuan untuk mengetahui pengaruh berat pati dan variasi volume gliserol terhadap karakteristik film plastik pati kentang. Pembuatan film plastik menggunakan metode blending pati dengan variasi berat pati kentang (10 g, $15 \mathrm{~g}$, dan $20 \mathrm{~g})$ serta variasi volume gliserol $(0 \mathrm{ml}, 1 \mathrm{ml}, 2 \mathrm{ml}$ dan $3 \mathrm{ml})$. Analisa bioplastik meliputi uji FTIR, kekuatan tarik yang didukung oleh analisa SEM. Hasil yang diperoleh pada analisa FTIR tidak terbentuk gugus baru pada film plastik pati kentang, baik pada film plastik tanpa gliserol maupun film plastik dengan gliserol. Hasil FTIR yang diperoleh pada kedua film plastik adalah perubahan regangan gugus $\mathrm{OH}, \mathrm{C}=\mathrm{C}$, dan $\mathrm{C}-\mathrm{H}$. Nilai regangan untuk gugus $\mathrm{OH}$ pada pati kentang adalah $3579,88 \mathrm{~cm}^{-1}$ berubah menjadi $2978,09 \mathrm{~cm}^{-1}$ untuk film plastik tanpa gliserol sedangkan untuk film plastik dengan gliserol menjadi $3541,31 \mathrm{~cm}^{-1}$ dan $2970,38 \mathrm{~cm}^{-1}$. Gugus $\mathrm{C}=\mathrm{C}$ dari $1635,64 \mathrm{~cm}^{-1}$ menjadi $1697,36 \mathrm{~cm}^{-1}$ dan $1697,36 \mathrm{~cm}^{-1}$. Sedangkan untuk gugus C-H dari $2873,79 \mathrm{~cm}^{-1}$ menjadi $2877,79 \mathrm{~cm}^{-1}$ dan $2870,08 \mathrm{~cm}^{-1}$. dan Kekuatan tarik film plastik mengalami penurunan dengan bertambahnya volume gliserol. Kekuatan tarik maksimum pada film plastik terjadi pada saat berat pati $10 \mathrm{~g}$ dan volume gliserol $0 \mathrm{ml}$ yaitu 9,397 MPa. Sedangkan hasil SEM yang diperoleh menguatkan hasil kekuatan tarik pada film plastik, dimana terdapat void, lekukan dan gumpalan pati yang tidak larut yang dapat mempengaruhi nilai kekuatan tarik film plastik.
\end{abstract}

Kata kunci: pati kentang, gliserol, blending, kekuatan tarik

\begin{abstract}
Bioplastics are plastics which can be degraded by microorganisms and is made from renewable materials. Plastic film is made from potato starch (contain of starch that founded in potatoes is 22-28\%), glycerol as a plasticizer and acetic acid as a catalyst. The purpose of this reasearch is to determine glycerol variation and starch weight effect on the characteristics of potato starch plastic films. Manufacture of plastic films use blending starch method with potato starch weight variations $(10 \mathrm{~g}, 15 \mathrm{~g}$ and $20 \mathrm{~g})$ and glycerol volume variations $(0 \mathrm{ml}, 1 \mathrm{ml}, 2 \mathrm{ml}$ and $3 \mathrm{ml})$. Bioplastic analysis are FTIR test, tensile strength that is supported by SEM analysis. The results obtained in the FTIR analysis does not form a new cluster on potato starch plastic film, neither on the plastic film with or without glycerol. FTIR results obtained in two plastic film are the change of $\mathrm{OH}, \mathrm{C}=\mathrm{C}$, and $\mathrm{CH}$ groups strain. The strain value of $\mathrm{OH}$ group on potato starch is 3579.88 $\mathrm{cm}^{-1}$ turned into $2978.09 \mathrm{~cm}^{-1}$ for plastic film without glycerol while the plastic film with glycerol to be $3541.31 \mathrm{~cm}^{-1}$ and $2970.38 \mathrm{~cm}^{-1} . \mathrm{C}=\mathrm{C}$ group is $1635.64 \mathrm{~cm}^{-1}$ turned to $1697.36 \mathrm{~cm}^{-1}$ and $1697.36 \mathrm{~cm}^{-1}$. As for CH group is $2873.79 \mathrm{~cm}^{-1}$ turned to $2877.79 \mathrm{~cm}^{-1}$ and $2870.08 \mathrm{~cm}^{-1}$. And tensile strength of plastic film decreased with increasing glycerol volume. Maximum tensile strength of plastic film occurs when potato starch weight is $10 \mathrm{~g}$ and glycerol volume is $0 \mathrm{ml}$ is $9.397 \mathrm{MPa}$. While SEM results obtained confirm on tensile strength plastic film, where there are voids, indentations and insoluble starch clump starch that can affect the value of tensile strength plastic film.
\end{abstract}

Keywords: potato starch, glycerol, blending, tensile strength

\section{Pendahuluan}

Konsumsi plastik di Indonesia pada tahun 2013 mencapai 26.000 ton per hari [16]. Konsumsi plastik yang berlebihan sangat berpotensi menjadi material yang mengancam kelangsungan makhluk hidup di bumi [11]. Usaha yang dapat dilakukan untuk mengurangi konsumsi plastik adalah dengan mensintesis polimer (bahan baku pembuatan polimer atau plastik) yang dapat terdegradasi oleh mikroba tanah, salah satu komponen yang digunakan harus material yang dapat diuraikan oleh mikroba [5]. Bahan pembuat plastik dapat berupa pati. Pati digunakan karena mudah terdegradasi oleh alam. Dan salah satu penghasil pati yang ada di Indonesia adalah kentang. Kandungan pati pada kentang adalah $22-28 \%$ [22].

Peneliti terdahulu telah melakukan berbagai cara untuk membuat plastik yang dapat didegradasi oleh alam. Salah satunya seperti yang yang dilakukan oleh Firdaus dan Anwar dengan judul Potensi Limbah Padat Cair Industri Tepung Tapioka sebagai Bahan Baku Film Plastik Biodegradable disebutkan bahwa pembuatan plastik biodegradable dari limbah padat-cair industri tepung tapioka sebagai bahan baku dan gliserol sebagai plasticizer pada temperature 80-90 
${ }^{\circ} \mathrm{C}$. Hasil menunjukkan bahwa kondisi optimum diperoleh kekuatan tarik 3,925 $\mathrm{MPa}$, persentase pemanjangan di peroleh 9,217\% [8].

Berdasarkan uraian di atas maka dilakukan kajian pembuatan film plastik dari pati kentang dengan penambahan berat pati kentang dan plasticizer (gliserol) untuk memperbaiki sifat kekuatan tarik dari plastik tersebut.

\section{Teori}

Bioplastik merupakan plastik yang dapat terdegradasi dan terbuat dari bahan terbaharui [17]. Bioplastik dapat digunakan layaknya plastik konvensional dapat terurai oleh aktivitas mikroorganisme [19]. Salah satu bahan yang dapat diperbaharui oleh alam adalah biji-bijian dan umbiumbian.

Biji-bijian (gandum, beras, jagung, barley) serta umbi seperti kentang sangat kaya akan pati. Pati dapat dipisahkan menjadi 2 fraksi, yaitu amilosa dan amilopektin. Pati alan terdiri atas amilosa sebanyak 10-20 \% dan amilopektin sebesar 80$90 \%$ [18].

Penggunaan pati pada pembuatan bioplastik ini telah dimulai pada tahun 70-an [1]. Pada penelitian ini pati yang digunakan adalah pati yang bersal dari kentang. Kentang (Solanum tuberosum L.) merupakan lima kelompok besar makanan pokok dunia selain gandum, jagung, beras dan terigu. Bagian utama kentang yang menjadi bahan makanan adalah umbi yang merupakan sumber karbohidrat, mengandung vitamin dan mineral yang cukup tinggi [16]. Tabel 1 menunjukkan sifat beberapa jenis pati.

Tabel 1. Sifat Beberapa Jenis Pati [22]

\begin{tabular}{|l|c|c|c|c|}
\hline Sumber & $\begin{array}{c}\text { Pati } \\
(\%)\end{array}$ & $\begin{array}{c}\text { Amilosa } \\
(\%)\end{array}$ & $\begin{array}{c}\text { Amilo- } \\
\text { pektin } \\
(\%)\end{array}$ & $\begin{array}{c}\text { Suhu } \\
\text { gelatinisasi } \\
(\mathbf{\%} \text { C) }\end{array}$ \\
\hline Jagung & $64-74$ & 26 & 74 & $62-70$ \\
\hline Gandum & $\begin{array}{c}87,2- \\
93,5\end{array}$ & 26 & 74 & $68-75$ \\
\hline Beras & $60-77$ & 1 & 99 & $67,5-74$ \\
\hline Sorgum & $57-74$ & 17 & 83 & $58,5-70$ \\
\hline Tapioka & $14-28$ & 20 & 80 & - \\
\hline Kentang & $22-28$ & 26 & 74 & $72-74$ \\
\hline
\end{tabular}

Plasticizer adalah bahan yang digunakan untuk mengubah sifat dan karakteristik pembentukan plastik [3]. Salah satu contoh dari plasticizer adalah gliserol. Gliserol memiliki kemampuan untuk mengurangi ikatan hidrogen internal pada ikatan intermolecular [14]. Sifat gliserol dapat dilihat pada Tabel 2.

Selain penggunaan pati sebagai bagan baku, kitosan juga dapat digunakan sebgai bahn baku. Adapun beberapa keuntungan dari kitosan adalah kitosan murah, dapat diperbaharui dan berlimpah. Disamping itu, kitosan banyak ditemukan di beberapa bagian yang sesuai dari bahan bakunya [1]. Kitosan adalah polisakarida linear. Polisakarida struktur karbohidrat polimer, yang terbentuk dari pengulangan unit (tiap mono- ataupun di- sakarida) yang tergabung bersama dengan ikatan glikosidik. Kitosan adalah polisakarida kedua yang sangat berlimpah di alam setelah selulosa. Biopolimer ini kebanyakan tersedia dari limbah produk pada industri kerang-kerangan. Kitosan juga dapat terbentuk dari komponen kitin dari fungsi dinding sel [13]. Sifat fisika kitosan dapat dilihat pada Tabel 3.

Tabel 2. Sifat Fisik- Kimia Gliserol [23]

\begin{tabular}{|l|l|}
\hline \multicolumn{1}{|c|}{ Sifat } & \multicolumn{1}{c|}{ Nilai } \\
\hline Tampilan fisik & Cair \\
\hline Kemurnian & $95-99,5 \%$ \\
\hline Titik didih & $290{ }^{\circ} \mathrm{C}$ pada $1013 \mathrm{hPa}$ \\
\hline Densitas relative & 1,26 pada $20^{\circ} \mathrm{C}$ \\
\hline Viskositas & $1410 \mathrm{mPa}$ s pada $20^{\circ} \mathrm{C}$ \\
\hline $\begin{array}{l}\text { Tegangan } \\
\text { permukaan }\end{array}$ & $63,4 \mathrm{Mn} / \mathrm{m}$ pada $20^{\circ} \mathrm{C}$ \\
\hline
\end{tabular}

Tabel 3. Sifat Fisika Kitosan [2]

\begin{tabular}{|l|l|}
\hline \multicolumn{2}{|c|}{ Spesifikasi } \\
\hline Penampilan & Putih atau kuning \\
\hline Bau & Tidak berbau \\
\hline Kelembaban & Max. 12 \% \\
\hline De-asetilasi & Min. 70 \% \\
\hline Viskositas & Max. 50 cps \\
\hline Transparansi & Min. 30 cm \\
\hline pH (dispersei 5\%) & $6,5-7,5$ \\
\hline Ukuran partikel & $20-30$ mesh \\
\hline Kelarutan & Min. 99\%, dalam $\mathrm{HCl} \mathrm{6 \%}$ \\
\hline
\end{tabular}

\section{Metodologi \\ Bahan Baku}

Bahan baku yang digunakan pada penelitian ini adalah kentang diperoleh dari Pasar Sei Kambing, Medan.

\section{Prosedur Penelitian}

Prosedur kerja dari penelitian ini terdiri dari 3 tahap, yaitu isolasi pati kentang, pembuatan film plastik dan karakterisasi hasil penelitian.

\section{Isolasi Pati Kentang}

Isolasi pati kentang dimulai dengan menimbang $100 \mathrm{~g}$ kentang yang kemudian dihaluskan. Kentang yang telah dihaluskan ditambahkan air sebanyak $100 \mathrm{ml}$ dan kemudian disaring. Biarkan selama 5 menit hasil dari penyaringan untuk pengendapan pati. Setelah pati mengendap, buang airnya sehingga meninggalkan pati [5].

\section{Pembuatan Film Bioplastik}

Pembuatan film plastik ini dilakukan dengan memasukkan air sebanyak $100 \mathrm{ml}$ ke dalam Beaker gelas dan ditambahkan pati sebanyak $10 \mathrm{~g}$, asam asetat $3 \mathrm{ml}$, dan gliserol $0 \mathrm{ml}$. Campuran pati tersebut dipanaskan dengan menggunakan magnetic stirrer hotplate selama 1 jam pada 
temperatur $72-74{ }^{\circ} \mathrm{C}$ hingga terbentuk gelatin. Kemudian diukur $\mathrm{pH}$ pada larutan, tambahkan $\mathrm{NaOH} 0,1 \mathrm{M}$ sampai $\mathrm{pH}$ pada larutan netral. Setelah terbentuk gelatin, ditambahkan kitosan $1 \%$ sebanyak $100 \mathrm{ml}$ kedalam larutan pati kentang. Panaskan hingga terjadi gelatinisasi kembali. Larutan yang telah tergelatinisasi dituang ke dalam cetakan akrilik untuk proses pencetakan, lalu didiamkan selama 2x24 jam di ruangan bertemperatur normal. Kemudian proses tersebut diulang untuk variasi yang lain [5].

\section{Karakterisasi Hasil Penelitian}

Film bioplastik pati kentang dengan dimensi $120 \mathrm{~mm}$ x $25 \mathrm{~mm}$ (Gambar 1), di uji (Fourier Trasmitter Infra Red) FTIR dengan menggunakan alat SHIMADZU IR-PRESTIGE 21 dan uji kekuatan tarik menggunakan alat ZEISS dengan perbesaran 100x.

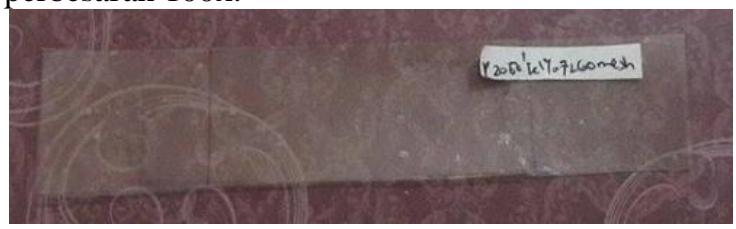

Gambar 1. Spesimen film plastik untuk pengujian FTIR dan kekuatan tarik

\section{Hasil dan Pembahasan}

Analisa Fourier Trasmitter Infra Red (FTIR) Pada Pati Kentang, Film Bioplastik Tanpa Gliserol, dan Film Bioplastik Pati Kentang Dengan Gliserol

Berikut merupakan gambar hasil analisa.

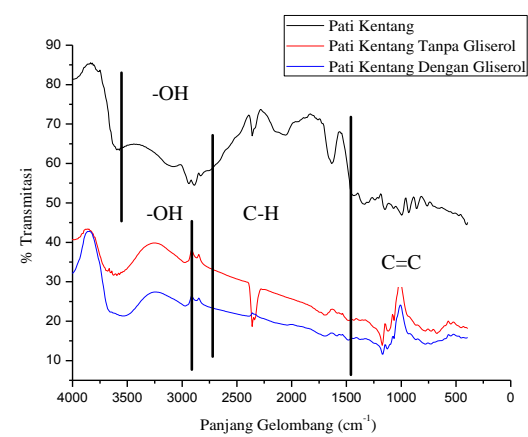

Gambar 2. Hasil Analisis FTIR

Pada Gambar 2 dapat terlihat bahwa pada pati kentang mula-mula gugus $\mathrm{OH}$ pada regangan $3579,88 \mathrm{~cm}^{-1}, \mathrm{C}=\mathrm{C}$ alifatik pada regangan 1635,64 $\mathrm{cm}^{-1}$ dan C-H alkana pada regangan $2823,79 \mathrm{~cm}^{-1}$. Setelah adanya proses pemanasan menjadi film plastik tanpa gliserol (pada Gambar 2 garis warna merah) intensitas regangan gugus $\mathrm{OH}$ menjadi $2978,09 \mathrm{~cm}^{-1}, \mathrm{C}=\mathrm{C}$ alifatik pada regangan 1697,36 $\mathrm{cm}^{-1}$ dan C-H alkana pada regangan $2877,79 \mathrm{~cm}^{-1}$. Sedangkan pada film plastik pati kentang dengan gliserol intensitas regangan gugus $\mathrm{OH}$ alkohol menjadi $3541,31 \mathrm{~cm}^{-1}$ dan $\mathrm{OH} 2970,38 \mathrm{~cm}^{-1}, \mathrm{C}=\mathrm{C}$ alifatik pada regangan $1697,36 \mathrm{~cm}^{-1}, \mathrm{C}=\mathrm{C}$ aromatik pada regangan $1589,34-1481,33 \mathrm{~cm}^{-1}$ dan $\mathrm{C}-\mathrm{H}$ alkana pada regangan $2870,08 \mathrm{~cm}^{-1}$.

Tabel 4. Hasil Pembacaan Analisis FTIR [21]

\begin{tabular}{|c|c|c|c|c|}
\hline $\begin{array}{c}\text { Panjang } \\
\text { Gelombang } \\
\left(\mathbf{c m}^{-1}\right)\end{array}$ & Regang & $\begin{array}{c}\text { Pati } \\
\text { Kentang } \\
\left(\mathbf{c m}^{-1}\right)\end{array}$ & $\begin{array}{c}\text { Film } \\
\text { Plastik } \\
\text { Tanpa } \\
\text { Gliserol } \\
\left(\mathbf{c m}^{-1}\right)\end{array}$ & $\begin{array}{c}\text { Film } \\
\text { Plastik } \\
\text { Dengan } \\
\text { Gliserol } \\
\left(\mathbf{c m}^{-1}\right)\end{array}$ \\
\hline $3500-3200$ & $\begin{array}{l}\mathrm{O}-\mathrm{H} \\
\text { alkohol }\end{array}$ & - & - & 3541,31 \\
\hline $3300-2500$ & $\begin{array}{l}\mathrm{O}-\mathrm{H} \\
\text { karboksil }\end{array}$ & 3579,88 & 2978,09 & 2970,38 \\
\hline $1680-1600$ & $\begin{array}{l}\mathrm{C}=\mathrm{C} \\
\text { alifatik }\end{array}$ & 1635,64 & 1697,36 & 1697,36 \\
\hline $1650-1430$ & $\begin{array}{l}\mathrm{C}=\mathrm{C} \\
\text { aromatik }\end{array}$ & - & - & $\begin{array}{l}1589,34- \\
1481,33\end{array}$ \\
\hline $3000-2850$ & $\begin{array}{l}\mathrm{C}-\mathrm{H} \\
\text { alkana }\end{array}$ & 2823,79 & 2877,79 & 2870,08 \\
\hline
\end{tabular}

Hasil FTIR pada Tabel 4 menunjukkan bahwa proses pembuatan film plastik merupakan proses pencampuran fisik dengan adanya interaksi hidrogen antar rantai.

\section{Pengaruh Berat Pati dan Volume Plasticizer Gliserol Terhadap Sifat Kekuatan Tarik Film Bioplastik Pati Kentang}

Gambar berikut menunjukkan hasil pengujian kekuatan tarik film plastik :

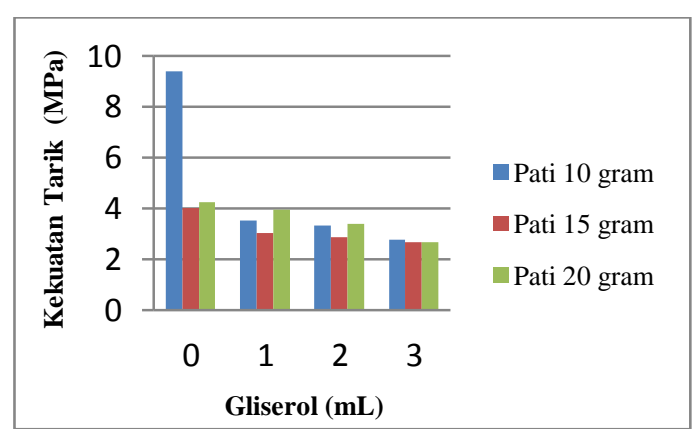

Gambar 3. Pengaruh Berat Pati dan Volume Plasticizer Gliserol Terhadap Kekuatan Tarik Film Bioplastik Pati Kentang

Dari Gambar 3 dapat kita lihat dengan bertambahnya volume gliserol maka kekuatan tarik (tensile strength) pada film bioplastik tersebut semakin menurun. dilihat dari film bioplastik pati kentang dengan berat pati $10 \mathrm{~g}$ dengan penambahan volume gliserol $0 \mathrm{ml}, 1 \mathrm{ml}, 2 \mathrm{ml}$ dan $3 \mathrm{ml}$ penurunan kekuatan tarik terjadi seiring bertambahnya gliserol tersebut, yaitu 9,397 MPa, 3,513 MPa, 3,329 MPa dan 2,753 MPa. Begitu juga untuk film bioplastik dengan berat pati $15 \mathrm{~g}$ dan 20 $\mathrm{g}$ dengan penambahan volume gliserol yang sama penurunan kekuatan tarik juga terjadi yaitu 4,024 $\mathrm{MPa}, 3,038 \mathrm{MPa}, 2,859 \mathrm{MPa}$ dan 2,652 MPa pada berat pati $15 \mathrm{~g}$ sedangkan pada pati $20 \mathrm{~g}$, yaitu 4,239 MPa, 3,954 MPa, 3,401 MPa, dan 2,676 MPa. Hal ini dikarenakan penambahan gliserol pada film 
bioplastik pati kentang ini akan menurunkan tegangan antar molekul yang menyusun matrik pada film bioplastik. Sehingga menyebabkan film bioplastik akan semakin lemah terhadap perlakuan mekanis yang tinggi.

Penurunan nilai kekuatan tarik dikarenakan dengan penambahan volume gliserol akan menurunkan kemampuan dispersi dari padatan sehingga menghasilkan sifat fisik yang lemah terhadap film bioplastik. Penambahan gliserol menyebabkan penurunan gaya tarik antar molekul sehingga menyebabkan ketahanan terhadap perlakuan mekanis film bioplastik tersebut akan semakin menurun.

Plasicizer merupakan bahan tambahan pada pembuatan film dari polimer. Plasicizer akan mengurangi gaya intermolekul yang dapat menyebabkan peningkatan ruang molekul dan mobilitas dari biopolimer. Grup polar $(-\mathrm{OH})$ di sekitar rantai plasicizer menyebabkan pengembangan ikatan hidrogen polimer-plastik yang menggantikan interaksi polimer-polimer pada film biopolimer. Peningkatan konsentrasi gliserol akan menghasilkan pengurangan interaksi intermolekul sehingga pergerakan dari rantai molekul akan turun [12].

Dari Gambar 2 juga dapat dilihat bahwa dengan bertambahnya berat pati kentang nilai kekuatan tarik mengalami fluktuatif. Dapat kita lihat nilai kekuatan tarik dari pati 10 gr mengalami penurunan pada film plastik dengan berat pati kentang $15 \mathrm{gr}$ kemudian naik kembali pada saat berat pati 20 gr. Seperti pada volume gliserol $0 \mathrm{ml}$ dengan berat pati $10 \mathrm{~g}, 15 \mathrm{~g}$ dan $20 \mathrm{~g}$ nilai kekuatan tariknya, yaitu 9,397 $\mathrm{MPa}, 4,204 \mathrm{MPa}$ dan 4,239 MPa. Pada saat volum gliserol $1 \mathrm{ml}$ nilai kekuatan tarinya seiring bertambahnya berat pati yaitu, 3,513 $\mathrm{MPa}, 3,038$ $\mathrm{MPa}, 3,954 \mathrm{MPa}$. Hal ini juga terjadi pada saat volume gliserol $2 \mathrm{ml}$ dan $3 \mathrm{ml}$, yaitu 3,329 $\mathrm{MPa}$, 2,859 $\mathrm{MPa}$, dan 3,401 $\mathrm{MPa}$ pada saat volum gliserol $2 \mathrm{ml}$ sedangkan pada saat volume gliserol 3 ml nilai kekuatan tariknya, yaitu 2,753 $\mathrm{MPa}, 2,652$ $\mathrm{MPa}$ dan 2,676 $\mathrm{MPa}$. Adanya penurunan dan kenaikan ini diduga karena sifat pati yang tidak larut dalam air kecuali pati telah dimodifikasi [12]. Sehingga menyabakan interaksi antara pati dengan air ataupun gliserol yang bersifat hidrofilik [3] tidak terjadi dengan baik.

\section{Analisa Scanning Electron Microscopy (SEM) Film Bioplastik Tanpa Gliserol dan Film Bioplastik Dengan Gliserol}

Dari Gambar 3(a) dapat dilihat morfologi dari film plastik pati kentang tersebut memiliki struktur permukaan yang tidak rata, dapat kita lihat pada gambar terdapat lekukan-lekuakan dipermukaan film plastik tersebut. Sedangkan pada Gambar 3(b) dapat dilihat bahwa terdapat lekukan-lekukan yang menunjukkan permukaan film tidak rata dan juga terdapat gumpalan pati yang tidak larut pada saat proses pembuatan film plastik.

Berikut merupakan gambar hasil analisa SEM:

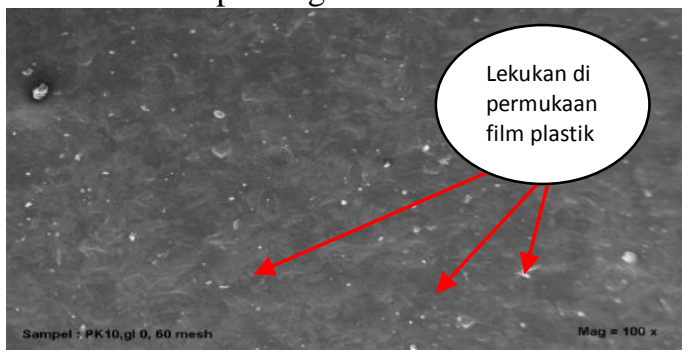

(a)

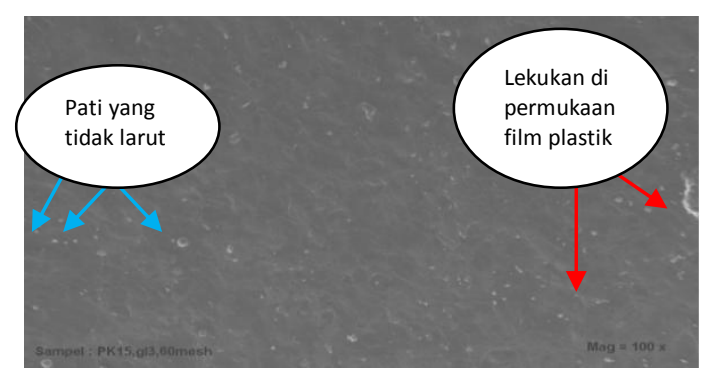

(b)

Gambar 4. Hasil Analisa SEM

(a) Film Plastik Pati Kentang Tanpa Gliserol 100x

(b) Film Plastik Pati Kentang Dengan Gliserol 100x

\section{Kesimpulan}

Kesimpulan yang diperoleh dari penelitian ini adalah :

1. Film plastik pati kentang dibuat dengan metode blending.

2. Dari hasil analisis FT-IR terhadap pati kentang, film bioplastik pati kentang tanpa gliserol, dan film bioplastik pati kentang tanpa gliserol diketahui tidak ada terbentuk gugus baru yang terjadi adalah pergeseran regangan gugus $\mathrm{OH}$, $\mathrm{C}=\mathrm{C}$, dan $\mathrm{C}-\mathrm{H}$ pada film bioplastik tersebut. Nilai regangan untuk gugus $\mathrm{OH}$ pada pati kentang adalah $3579,88 \mathrm{~cm}^{-1}$ berubah menjadi $2978,09 \mathrm{~cm}^{-1}$ untuk film plastik tanpa gliserol sedangkan untuk film plastik dengan gliserol menjadi $3541,31 \mathrm{~cm}^{-1}$ dan $2970,38 \mathrm{~cm}^{-1}$. Gugus $\mathrm{C}=\mathrm{C}$ dari $1635,64 \mathrm{~cm}^{-1}$ menjadi $1697,36 \mathrm{~cm}^{-1}$ dan $1697,36 \mathrm{~cm}^{-1}$. Sedangkan untuk gugus $\mathrm{C}-\mathrm{H}$ dari $2873,79 \mathrm{~cm}^{-1}$ menjadi 2877,79 $\mathrm{cm}^{-1}$ dan $2870,08 \mathrm{~cm}^{-1}$

3. Nilai kekuatan tarik akan menurun seiring bertambahnya volume gliserol. Nilai kekuatan tarik maksimal film bioplastik pati kentang diperoleh pada saat variasi volume gliserol $0 \mathrm{ml}$ dengan berat pati kentang yaitu sebesar 9,397 MPa.

4. Dari hasil analisa SEM dapat dilihat bahwa permukaan film plastik yang terbentuk tidak rata. Ada beberapa lekukan, patahan serta void yang terbentuk pada film plastik pati kentang 


\section{Daftar Pustaka}

[1] Averous, Luc dan Olivier Vilpoux, Chapter 18 Starch-Based Plastics. Didalam : Book 3Technology, use and potentialities of Latin American Tubers. Proceeding of The Food Biopack Conference, Conference Copenhagen, Denmark, 2000. Hal : 521-549.

[2] Bio Chitosan Indonesia. Certificate of Analysis Chitosan. Bandung : CV Bio Chitosan Infonesia. 2013.

[3] Chillo, S., Flores S., Mastromatteo M., Contte A., Gherchenson L., dan Del Nobile M. A, Influence of Glycerol and Chitosan on Tapioca Starch-Based Edible Film Properties, Journal of Food Engineering, Vol. 88, (2008), p. $159-168$.

[4] Crawford, RJ. Plastics Engineering. $3^{\text {rd }}$ ed, John Willey \& Sons, Ltd, Singapura, 1998.

[5] Darni, Yuli dan Herti Utami, Studi Pembuatan dan Karakteristik Mekanik dan Hidrofobisitas Bioplastik dari Pati Sorgum, Jurnal Rekayasa Kimia dan Lingkungan, Vol.7, No.4. (2010), ISSN 1412-5064, p. 190-195.

[6] Desnelli dan Miksusanti, Studi Biodegradasi Blend PVC-Minyak Nabati Epoksi Sebagai Salah Satu Upaya Mengurangi Pencemaran Lingkungan Oleh Limbah Plastik. Jurnal Penelitian Sains, Vol.13, No.2(C)13207, (2010), p. 33-36

[7] Dutta, Pradip Kumar, Joydeep Dutta dan V S Triphati, Chitin and Chitosan : Chemistry, Properties and Applications, Journal of Scientific \& Industrial Reaserch, Vol 63, (2004), p. 20-31

[8] Firdaus, Feris dan Chairil Anwar, Potensi Limbah Padat-Cair Indutri Tepung Tapioka sebagai Bahan Baku Film Plastik Biodegradabel, Jurnal LOGIKA, Vol.1, No.2, (2004), ISSN 1410-2315, p. 38-44.

[9] Griffin, G. J. L, Chemistry and Technology of Biodegradable Polimer. Chapman \& Hall, London, 1994.

[10] Helmy, Mohammad, Extended Producer Responsibility : Pendekatan Baru Pertanggungjawaban Para Produsen, Majalah Kelopak : Sumber Invormasi Kelola Sampah dengan Bijak, Edisi 1, (2013), p. 6-9.

[11] Huda, Thorikul, dan Feris Firdaus, Karakteristik Fisiokimiawi Film Plastik Biodegradable dari Komposit Pati SingkongUbi Jalar, Jurnal LOGIKA, Vol. 4, No.2, ISSN 1410-2315, (2007).

[12] Huri, Daman dan Fitri Choirun Nisa, Pengaruh Konsentrasi Gliserol dan Ekstrak Ampas Kulit Apel Terhadap Karakteristik Fisik dan Kimia Edible Film (The Effect of Glycerol and Apple Peel Waste Extract Concentration on Physical and Chemical Characteristic of Edible Film), Jurnal Pangan dan Agroindustri, Vol. 2, No. 4, (2013), p. 29-40.

[13] Husniati, Studi Karakterisasi Sifat Fungsi Maltodekstrin Dari Pati Singkong (Study On Characterization of Functional Properties of Maltodextrin of Cassava Slurry), Jurnal Riset Industri, Vol III, No. 2, (2009), p. 133-138

[14] Kirk dan Othmer, Encyclopedia of Chemical Technology, Vol. 12, Edisi 4, John Wiley \& Sons Inc, New York, 2012.

[15] Nadiah, Nurul Binti Md Aini, Thesis Biodegradable Biocomposite Strach Based Film Blanded With Chitosan And Gelatin, Universiti Malaysia Pahang, Malaysia, 2010.

[16] Nurdin, Endang, Upaya Mengurangi Jutaan Kantong Plastik, BBC Indonesia, http:// bbc.co.uk/Indonesia/ majalah/2014/ 01/140118_bisnis_sosial_greeneration, 2014, diakses pada 26 Januari 2015.

[17] Nuriah, Lailatin., Iswarin, Siti Jazimah., Wiyono, Karakteristik Sifat Mekanik Bioplastik dari Pati Ubi Kayu Dengan Pemplastis Gliserol dan Sorbitol, Jurnal Natural B, Vol. 1, No.1, (2011).

[18] Ophardt, Charles E, Starch, Virtual Chembook El mhusrt Collage. http://www.elmhurst.edu/ chm/vchembook/5 47starch.html, 2003.

[19] Pranamuda, Pengembangan Bahan Film Plastik Berbahan Baku Pati Tropis, Hasil Penelitian dan Badan Pengkajian Dan Penerapan Teknologi, Jakarta, 2011.

[20] Sanjaya, G. L. dan Puspita, L, Skripsi Pengaruh Penambahan Khitsan dan Plasticizer Gliserol pada Karakteristik Plastik Biodegradable dari Pati Limbah Kulit Singkong, Institut Teknologi Sepuluh Nopember, Surabaya, 2010.

[21] Stuart, Barbara, Infrared Spectroscopy : Fundamental and Applications. Jhon Wiley, Amerika, 2004.

[22] Sunarti TC, Nunome T, Yoshio N, Hisamatsu M, Study on outer chains from amylopectin between immobilized and free debranching enzymes, Journal of Applied Glycoscience, Vol.48, No.1, ISSN : 1344-7882, (2002), p. 1-10.

[23] UNEP, Glycerol, http://www.chem. unep.ch/sids/oecdsids/56815.pdf, 2002, diakses pada 12 juni 2012. 